\title{
UNA BELLEZA INCÓMODA: ANORMALIDAD Y MONSTRUOSIDAD EN SALÓN DE BELLEZA, DE MARIO BELLATIN
}

\author{
Felipe Adrián Ríos Baeza \\ Universidad Anáhuac, Campus Querétaro (México) \\ felipe.rios@anahuac.mx
}

RESUMEN: El presente artículo busca estudiar las nociones de anomalía y monstruosidad, presentes en el enfoque crítico del filósofo Michel Foucault, en la novela corta Salón de belleza (1994) del escritor mexicano Mario Bellatin. Desde esta perspectiva, podrá evidenciarse cómo ciertos agentes anormales en la narración posibilitan que un personaje o un espacio mute hacia algo inhumano. La manera en la cual se analizará esta novela - cuya reedición conmemorativa en 2014 la ha ubicado al centro de la polémica por asuntos legales, pero también literariospuede servir para interpretar la totalidad del corpus narrativo del mexicano. Y es que la literatura de Bellatin tiene algo que es propio de todo escritor magnánimo: tiende a la belleza, sí. Pero incomoda.

PALABRAS CLAVE: Mario Bellatin, monstruosidad, anormalidad, mutación, Michel Foucault

\begin{abstract}
This article's objective is to study the notions of anomaly and monstrosity, present in Michel Foucault's critical focus of the novel Salón de belleza (Beauty Salon, 1994) from the Mexican author Mario Bellatin. From this perspective, it will be evident that certain abnormal agents in the narration let a character or space mutate into something non-human. The way in which this novel — of which the commemorative issue in 2014 has led to some controversy due to legal issues - will be analyzed can help interpreting the totality of the narrative corpus of the Mexican author. And it is because Bellatin's narrative has the characteristic of every magnanimous writer: it tends to be beautiful, indeed. But it is also awkward.
\end{abstract}

KEYWORDS: Mario Bellatin, monstrosity, abnormality, mutation, Michel Foucault

\section{Una belleza incómoda}

Tematológicamente, la totalidad de la obra de Mario Bellatin (Ciudad de México, 1960) puede estudiarse desde un mismo enfoque, que puede agruparla y distinguirla como singular no sólo en la narrativa mexicana contemporánea, sino en la totalidad de las letras del continente. Dicho enfoque es el de una anomalía, que se introduce subrepticiamente en la narración; una anormalidad que en un principio inquieta, pero que luego deviene en una monstruosidad capaz de acaparar toda la narración. Independiente de los argumentos y de los lugares donde estos se

Felipe Adrián Ríos Baeza: "Una belleza incómoda: anormalidad y monstruosidad en Salón de belleza, de Mario Bellatin" 
desenvuelvan, desde Mujeres de sal (1986) hasta su última entrega, Retrato de Mussolini con familia (2015), pasando por Shiki Nagaoka: una nariz de ficción (2001), Jacobo el mutante (2002) y El libro uruguayo de los muertos (2012), por nombrar sólo algunos, Bellatin expone una situación inicial estable, que luego irá mutando, trastocándose, hasta que las fronteras visibles entre el hombre y la bestia (que equivale a decir entre lo humano y lo inhumano) se difuminen, permitiendo que el lector ingrese en una zona de diseminación narrativa y hasta ética.

Ya en 2005 la ensayista Diana Palaversich mencionaba, en el prólogo a la Obra reunida 1, que:

Bellatin con frecuencia compone sus textos como si fueran un thriller, invitando a suponer que detrás de cada cuerpo anómalo y de cada trama absurda se esconde un terrible secreto que el lector descubrirá al final. El lector arma las piezas del acertijo narrativo, busca (en vano) el orden original de eventos y la conexiones entre lo que a primera vista parecían elementos caóticos y no relacionados. Para desviar estos impulsos detectivescos, Bellatin tiende trampas narrativas, ofreciendo pistas (falsas) que prometen desentrañar el misterio del texto. (Palaversich, 2005: 1213)

Liberado de la represión de una narrativa progresiva, que presente siempre fuerzas en conflicto para hacer avanzar una trama; y liberado también de la obligación de que esa trama se resuelva (tal vez la más anquilosada herencia de la narrativa tradicional europea, replicada luego por algunos nombres del boom), Bellatin, más que componer, disemina. Aquello que Palaversich denomina "trampas" narrativas coincide con lo que aquí llamaré, al alero de la teoría de Michel Foucault, una anormalidad, elemento que logra, precisamente, ese desdibujado narrativo.

En el presente ensayo propongo estudiar este principio en la novela corta Salón de belleza, desde la perspectiva de los agentes anormales que posibilitan que un personaje o un espacio mute hacia algo monstruoso o inhumano. La manera en la cual se analizará dicha novela - cuya reedición conmemorativa en 2014 no ha estado exenta de polémica- ${ }^{1}$ puede servir para interpretar la totalidad del corpus narrativo del mexicano desde esta perspectiva. Y es que la literatura de Bellatin tiene algo que es propio de todo escritor magnánimo: tiende a la belleza, pero incomoda.

\section{Lo anormal y monstruoso en Michel Foucault}

En 1975, el filósofo Michel Foucault impartió un seminario en el Collège de France que luego se publicaría con el nombre de Les anormaux (Los anormales). En su clase del 22 de enero, aparecen trazadas, bajo las reflexiones pretéritas de Foucault en torno al tema de las redes de poder, varias de las figuras que introducen una anomalía en el marco sociocultural de Occidente.

\footnotetext{
${ }^{1}$ Cf. MORALES, Francisco: "Denuncia Mario Bellatin libro desautorizado", Reforma, 17 de septiembre de 2015, y también AGUILAR SOSA, Yanet: "Mario Bellatin gana la primera batalla contra Planeta-Tusquets", El Universal, 30 de octubre de 2015. Allí se explica el conflicto que se suscitó cuando Tusquets editó, sin autorización expresa del autor, una edición conmemorativa de Salón de belleza por sus veinte años. Los editores alegan que, aunque el contrato por los derechos de autor se vencía, este se renovaba automáticamente por otros quince años. Bellatin protestó jurídicamente al señalar que se había llevado a cabo un contrato con dolo y contra su voluntad, además de no haber recibido dinero alguno por las reimpresiones.
}

Felipe Adrián Ríos Baeza: "Una belleza incómoda: anormalidad y monstruosidad en Salón de belleza, de Mario Bellatin" 
Por un lado, se encuentra el individuo a corregir, fenómeno regular de las sociedades clásicas (las del siglo XVIII y XIX) de un sujeto que ha comenzado a desviarse de la norma —política, sexual, jurídica, etc.- , pero que tiene al gran agente socializador de la familia para encauzarlo de regreso. Por otro lado, está el masturbador, cuyo ámbito ya no es la sociedad, sino el espacio más estrecho del cuarto propio, el dormitorio, la microcélula doméstica. Al decir de Foucault, "ese secreto, que todo el mundo comparte y a la vez nadie comunica, se plantea en su cuasi universalidad como raíz posible, e incluso la raíz real de casi todos los males posibles [...]; es el principio de explicación de la singularidad patológica" (2006: 65). ${ }^{2}$ Finalmente, aparece el monstruo, la "infracción llevada a su punto máximo" (62). Un monstruo, tautológicamente, se aleja de lo humano. Un individuo aún humano es plausible de corregir bajo las lógicas de vigilancia y castigo del poder, para ser conducido, luego, hacia la normalidad (es decir, reorientado hacia el consenso discursivo en torno al ejercicio social en el ámbito público y como se ha visto con mayor agudeza con el concepto de biopolítica ${ }^{3}$ en el entorno privado). Pero si el monstruo infringe no solo la norma social sino la regla natural (debido a su carácter contranatural de mixtura) ${ }^{4}$ es evidente que su sola presencia pone delante del hombre normal (conducente con la norma) aquello que más lo altera. Lo monstruoso deshumaniza precisamente porque atenta contra la polaridad binaria (humano/animal; vida/muerte; bondad/maldad), haciendo ingresar al sujeto en un terreno que no desconoce; muy por el contrario: como lo conoce demasiado bien, le teme y le provoca rechazo. "[E]l monstruo es, en cierto modo, la forma espontánea, la forma brutal, pero, por consiguiente, la forma natural de la contranaturaleza", reafirma Foucault. "Es el modelo en aumento, la forma desplegada por los juegos de la naturaleza misma en todas las pequeñas irregularidades posibles. $Y$ en este sentido, podemos decir que el monstruo es el gran modelo de todas las pequeñas diferencias. Es el principio de inteligibilidad de todas las formas [...] de la anomalía [...]. En una palabra, digamos que el anormal [...] es el fondo un monstruo cotidiano, un monstruo trivializado" (62-63).

Son esas "pequeñas irregularidades" las que pondrán en funcionamiento una serie de estrategias por parte del poder, bien para asimilar con efectividad a ciertos anormales (bajo la lógica de la inclusión y vigilancia), bien para apartarlos sin remedio. El poder ejercerá sobre los individuos una represión maniquea, explicándose a sí mismos y a la sociedad, a través de la

\footnotetext{
${ }^{2}$ En lo que sigue, solo se indican las páginas del libro de Foucault en cuestión.

${ }^{3}$ Para mayor hondura en torno a cómo los procesos biológicos del sujeto y de la población son absorbidos y vigilados por el Estado, puede revisarse otro curso que impartió Foucault en el Collège de France, Defender la sociedad: "La biopolítica tiene que ver con la población, y ésta como problema político, como problema a la vez científico y político, como problema biológico y como problema de poder [...]. [Es] La consideración de la vida por parte del poder [...]; un ejercicio del poder sobre el hombre en cuanto ser viviente, una especie de estatización-de-lobiológico o al menos una tendencia conducente a lo que podría denominarse la estatización-de-lo-biológico" (2000: 222, 215).

${ }^{4}$ Para Foucault, el monstruo es "[1]a mezcla de dos reinos, reino animal y reino humano: el hombre con cabeza de buey, el hombre con patas de pájaro - monstruos-. Es la mixtura de dos especies, la mezcla de dos especies: el cerdo que tiene cabeza de carnero es un monstruo. Es la mixtura de dos individuos: el que tiene dos cabezas y un cuerpo, el que tiene dos cuerpos y una cabeza es un monstruo. Es la mixtura de los sexos: quien es a la vez hombre y mujer es un monstruo. Es una mixtura de vida y muerte: el feto que nace con una morfología tal que no puede vivir, pero que no obstante logra subsistir durante algunos días, es un monstruo" (2006: 68).
}

Felipe Adrián Ríos Baeza: "Una belleza incómoda: anormalidad y monstruosidad en Salón de belleza, de Mario Bellatin" 
categoría de lo monstruoso, aspectos o comportamientos "fuera de la ley", sea esta natural y/o jurídica.

Vuelvo a la cita de Palaversich con la que iniciaba este ensayo. Ella señala que "detrás de cada cuerpo anómalo y de cada trama absurda se esconde un terrible secreto que el lector descubrirá al final" (2005: 13. El énfasis es mío). Foucault insiste en la apariencia, las potencialidades, enfermedades, degeneraciones y abusos cometidos en un cuerpo porque, junto con el lenguaje, será la primera superficie donde el poder mostrará su dominación. Del mismo modo se evidenciará en Salón de belleza, de Mario Bellatin, cuando el propio cuerpo del protagonista y los cuerpos que recibe en su entorno de trabajo para su descomposición natural, se conviertan en la anomalía que, en un comienzo, se introduce en un ambiente amable, pero que acabará por saturar todo el espacio y toda la narración.

\section{De centro de estética a moridero: la mutación del salón}

"Me parece que en lo que se refiere al control de los individuos, Occidente no tuvo en el fondo más que dos grandes modelos: uno es el de la exclusión del leproso; el otro es el modelo de la inclusión del apestado" (Foucault, 2006: 52), explica Foucault en Los anormales, observando el fenómeno de los dispositivos de inclusión y exclusión de individuos desde los dos grandes flagelos sanitarios presentes desde la antigüedad: la lepra y la peste. Si para el caso de la lepra, la biopolítica actuaba marginando y estigmatizando a los enfermos (cuyo padecimiento se explicaba, en tanto causas y efectos, por maldiciones, castigos sobrenaturales, impureza moral, etc.); para el caso de la peste, al individuo se le dará tratamiento, poniéndolo en cuarentena en su propio hogar, para luego reinsertarlo en la sociedad al momento de su sanación.

Esa dinámica de la estigmatización (los normales segregando a los anormales, los morales a los inmorales, etc.); esa aplicación de violencia no solo física, sino también simbólica, fue la misma ejercida durante las décadas de 1980 y 1990 a las personas contagiadas con el virus de inmunodeficiencia adquirida. ${ }^{5}$ Ya con la lepra desterrada del escenario y del imaginario colectivo de Europa, y con la peste controlada, el VIH se erigió como la enfermedad "monstruosa" por excelencia. Estuvieron claros los síntomas e incluso, en gobiernos responsables, los tratamientos preventivos. Pero al desconocerse sus orígenes, el VIH constituyó un virus con características contranaturales, inhumanas e incluso siniestras. ${ }^{6}$

\footnotetext{
${ }^{5}$ En un ensayo de Elvis Rodríguez y Nelly García, muy en la línea crítica de este mismo ensayo, se afirma que "después del acto ritual del diagnóstico que permite a la biomedicina determinar si una persona es portadora del VIH/SIDA, se inicia un proceso de estigmatización, bajo la dinámica de oposición normal/anormal, que lleva consigo procesos de inclusión y exclusión tanto espaciales como relacionales que configuran un entramado de sentidos, haciendo percibir al enfermo como el monstruo que ataca a la sociedad" (2006).

${ }^{6}$ Según el texto de Sigmund Freud, lo siniestro o unheimlich describe el espanto que sobreviene cuando las cosas conocidas y familiares de pronto resultan extrañas y amenazantes. Lo que en un momento fue el máximo exponente de lo cercano y lo conocido (heimlich), se revierte de improviso en algo monstruoso, acechante y ajeno (unheimlich). En este caso, un virus que la medicina puede diagnosticar, pero no determinar su origen y, en un principio, tampoco determinar su cura, deviene en el elemento umheimlich del entorno. Vid. FREUD, Sigmund (1968): "Lo siniestro". En Obras completas VII. Madrid, Biblioteca Nueva, 2483-2500.
}

Felipe Adrián Ríos Baeza: "Una belleza incómoda: anormalidad y monstruosidad en Salón de belleza, de Mario Bellatin" 
Este es el contexto que se proyecta en Salón de belleza: un entorno en el que se desencadena una enfermedad y que Bellatin la agudiza al no darle nombre. Resulta evidente que la irrupción de la anomalía de los cuerpos enfermos en un centro de estética será el agente anormal más visible. No obstante, a pesar de su brevedad, Salón de belleza será una novela que presentará una serie de anomalías, en tanto alteración narrativa, que no conviene dejar de mencionar para el justo análisis que aquí se propone.

La historia está narrada por un protagonista anónimo, que luego de un pasado dramático - en su juventud escapó de casa de su madre, debido a que "nunca me perdonó que no fuera el hijo recto con el que ella había soñado" (Bellatin, 2005: 40), ${ }^{7}$ y viajó al norte del país donde trabajó en un "hotel para hombres"- decide montar un salón de belleza como una manera de construirse un futuro más amable. En un lugar donde el cuerpo femenino se interviene estéticamente y cambia de aspecto a través de peinados, coloraciones y retoques; en suma, en un lugar donde es posible alterar, aunque sea momentáneamente, el paso inevitable del tiempo, el protagonista cree que ha encontrado su entorno de humanización. No obstante, uno de los compañeros que trabajaban con él le solicita un favor, asunto que comenzará a movilizar la historia: "[M] contó que uno de sus amigos más cercanos estaba al borde de la muerte y no lo querían recibir en ningún hospital. Su familia tampoco quería hacerse cargo del enfermo y, por falta de recursos económicos, su única alternativa era morir debajo de uno de los puentes del río [...]" (42).

El salón de belleza, cargado hasta entonces de los anhelos por embellecer su propia existencia y las de las clientas (bajo el criterio de retrasar la inevitable descomposición del aspecto físico), comienza a convertirse en un recinto donde enfermos de ese mal innombrable acuden en su fase terminal. "Acepté sin pensar mucho en las consecuencias, pues de habérseme hecho ese pedido en otro momento jamás hubiera permitido que mi salón de belleza se convirtiera en un Moridero" (42), explica al comienzo. Y luego señala:

Aquel joven murió un mes después de su ingreso. Recuerdo que casi nos volvimos locos por tratar de restablecerlo. Convocamos a algunos médicos, enfermeras y yerberos. Visitamos también a personas que se dedicaban a la curandería. Hicimos algunas colectas entre los amigos para comprar las medicinas, que eran sumamente caras. Todos aquellos esfuerzos no fueron sino vano intento por estar en paz con nuestra conciencia. No sé dónde hemos aprendido que socorrer al desvalido es tratar de apartarlo, a cualquier precio, de las garras de la muerte. (42. El énfasis es mío)

Es aquí donde se presenta la primera anormalidad, debido al cambio paradigmático del protagonista. Si de forma suave y benévola el salón de belleza actuaba con los maquillajes, tinturas y pintura de uñas, como una manera de "apartar de las garras de la muerte" a las clientas complacientes, en el momento en que dicho recinto se convierta en "moridero", incluso el léxico utilizado se endurecerá, y ya no habrá intención por parte del personaje a volver amable ese paso del tiempo. Por el contrario, mientras más rápido y directo suceda el deceso del enfermo, más

\footnotetext{
${ }^{7}$ En lo que sigue, solo se indican el número de páginas correspondientes a la misma edición de Salón de belleza.
} 
sentido parece tener este cambio para el personaje: "Lo mejor era una muerte rápida dentro de las condiciones más adecuadas que fuera posible brindársele al enfermo" (42).

La anomalía, por tanto, se trastoca. Si lo normal, en un entorno de producción de belleza como el salón, era lo armónico y agraciado, lo anormal del grotesco cuerpo de los enfermos terminales irrumpirá no solo para cambiar el recinto, sino la visión del sujeto. Las nuevas reglas modifican dramáticamente el escenario: si antes solo se permitían mujeres (clientas que pagaban no solamente por un servicio de embellecimiento, sino también por la ilusión afable que los peluqueros pudieran otorgarle a su aspecto físico e incluso a su estado interior), ${ }^{8}$ ahora solo se aceptará a varones cuya apariencia, externa e interna, haya sido roída por el virus. Este cambio brusco de lo primoroso a lo desgraciado provoca que, ahora, lo normal sea la enfermedad y lo anormal, la sanidad: "Algunas veces, muchachos jóvenes y vigorosos tocaron las puertas", cuenta el narrador en un momento. "Aseguraban que estaban enfermos, e incluso algunos llevaban consigo los resultados de los análisis que los certificaban [...]. Yo tenía que sacar la misma fuerza que mostraba delante de las mujeres que pedían hospedaje y decirles que regresaran meses después. Que no volvieran a tocar las puertas sino hasta cuando sus cuerpos fueran irreconocibles. Con los achaques y la enfermedad desarrollada" (43).

La conversión del recinto en moridero tiene, por supuesto, reacciones en el entorno social, encarnando la lógica reactiva que planteaba Foucault en Los anormales al presentarse la simbolización de lo monstruoso (infectados de un virus siniestro, según la noción psicoanalítica, y de comportamiento impredecible). Al enterarse los vecinos de que allí se mantiene de manera arbitraria a jóvenes que solamente esperan su deceso, la comunidad se alerta: "La campaña que se desató en mi contra fue bastante desproporcionada", puede leerse. "Tanto, que cuando la gente quiso quemar el salón tuvo que intervenir hasta la misma policía. Los vecinos afirmaban que aquel lugar era un foco infeccioso, que la peste había ido a instalarse en sus dominios" (37). Los términos escogidos por Bellatin para relatar esta escena no son gratuitos: "quemar el salón", "foco infeccioso", "peste", "dominios". La reacción ante lo monstruoso, en cualquier época, ya sea la Edad Media o finales del siglo Xx, parece insuflar y generar el mismo patrón de comportamiento en el gentío, que vive y defiende lo que aparenta como normalidad. Ante lo monstruoso, la sociedad parece no acudir a la autoridad para la resolución del problema, sino que está dispuesta a ejercer por mano propia su cuota de poder. Entonces, se encienden antorchas y se habla con un vocabulario altisonante, intentando acabar con aquello que les parece amenazante (la enfermedad) o que no desean ver (el evento inevitable de la muerte).

No obstante, el "antiguo salón de belleza", o "nuevo moridero", trae aparejada una inquietud adicional: ¿de qué se trata, realmente, este nuevo recinto? ¿Puede determinarse? Esa indefinición es lo que pondrá a los vecinos, y al propio lector, en guardia. Al asumir definitivamente que los sillones y espejos del salón de belleza han dado paso a las camas improvisadas del moridero, el narrador explica:

\footnotetext{
8 "Fuimos adoptando también la costumbre de vestirnos así [como mujer] para atender a las clientas. Me pareció que de ese modo se creaba un ambiente más íntimo en el salón. Las clientas podían sentirse más a gusto. De esta forma podían contarnos quizá sus vidas, sus secretos. Sentirse aliviadas de sus problemas" (Bellatin, 2005: 41).
}

Felipe Adrián Ríos Baeza: "Una belleza incómoda: anormalidad y monstruosidad en Salón de belleza, de Mario Bellatin" 
Ahora tengo que regentar este Moridero. Debo darles una cama y un plato de sopa a las víctimas en cuyos cuerpos la enfermedad se ha desarrollado. Y lo tengo que hacer yo solo. Las ayudas son bastante esporádicas. De vez en cuando alguna institución se acuerda de nuestra existencia, y nos socorre con algo de dinero. Otros quieren colaborar con medicinas. Pero tengo que volver a recalcar que el salón de belleza no es un hospital ni una clínica, sino sencillamente un Moridero [...]. A pesar de que me parece estar acostumbrado a este ambiente, creo que para cualquiera sería ahora insoportable multiplicar la agonía hasta ese extraño infinito que producen los espejos puestos uno frente al otro. A lo que también parezco haberme acostumbrado es al olor de los enfermos. (31. El énfasis es mío)

No se trata, entonces, de una situación donde se disponga el espacio de manera humana, en la general lógica de un recinto para el "buen morir". Tampoco un lugar que persiga la sanación, sino solo un espacio sosegado de espera para que ocurra lo inevitable.

Por supuesto, el moridero implica la proyección de las fracturas de identidad del propio personaje. El espacio se trastoca de (si se me permite la licencia japonesa a lo Kawabata) lo bello a lo triste, lo que en ese momento específico de la narración será de la normalidad armónica del salón a la anormalidad monstruosa del moridero. No obstante, como se ha visto - y aún más: reforzado con la frase final de la cita anterior, "a lo que también parezco haberme acostumbrado es al olor de los enfermos" (31) _ , por fuerza de costumbre el entorno de la enfermedad y la muerte se vuelve la norma, y la vitalidad y vigor de los cuerpos sanos, lo anómalo. Es importante, pues, concentrarse ahora en este punto porque el cuerpo del propio protagonista, primero por influjo de un oficio y luego por la misma enfermedad (de la que es primero testigo y asistente, y luego, víctima), es el que irá mutando.

\section{De regente a huésped: el cuerpo del narrador}

Al comienzo se narra que el salón de belleza cerraba sus puertas a las ocho. Con toda la noche disponible, el protagonista y sus compañeros se ataviaban de mujer, con maquillaje y hasta pelucas, buscando "algo de diversión en los mezanines de algunos cines que proyectan en forma continua películas pornográficas. Los tres lo pasábamos especialmente bien cuando ciertos espectadores iban al baño" (32). Esas correrías comienzan a hacerse menos frecuentes cuando, asumiendo la mixtura de lo femenino en lo masculino como anormal y monstruoso, la sociedad los trata de marginar y reprimir de manera violenta: "[H]abíamos dado cobijo a uno que otro herido por la Banda de los Matacabros o por otro tipo de asaltantes" (42). De esta manera, los vestidos y cosméticos de mujer se guardarán, casi al mismo momento en que el espacio dispuesto como "salón de belleza" pierde vigor e importancia ante los ojos del protagonista: "Siento una alegría un tanto triste al comprobar que, de cierta forma, en los últimos tiempos el orden se ha instalado por primera vez en mi vida", opinará. "Aunque me parece algo sombría la forma de haberlo obtenido. Se acabaron las aventuras callejeras, las noches pasadas en celdas durante redadas, las peleas a pico de botella [...]" (41).

Ya se sabe: han desaparecido las secadoras y los sillones reclinables del antiguo local, permutándose por "colchones de paja, catres de fierro y una cocina de kerosene" (31). La anomalía de la enfermedad, por tanto, no intenta resarcirse, sino que se permite su continuidad 
para que se vuelva normalidad. Lo importante a notar aquí es lo siguiente: lo degradado se toma lo bello a fuerza de costumbre y, como el propio protagonista señala, se inicia en él, y en nosotros, una poderosa transformación interna. Dicho cambio no será otro que el de humano en monstruo cuando, antes que por el bienestar de los huéspedes, el narrador comience a velar, en realidad, por el mantenimiento del moridero: "Cuando el salón de belleza comenzó a cambiar, sentí también una transformación interna. Entre otras cosas, al momento de dar atención a los huéspedes me hice algo así como más responsable" (41). Es decir, cuando la institución, y no la persona, se convierte en el foco de atención y en objeto de dedicación exclusiva para el personaje, sobreviene esta inquietante mutación hacia una inhumanidad que implicará, al fin, el cambio narrativo más importante en la novela.

¿Qué significan, entonces, el orden y la estabilidad? El dibujo personal que hace Bellatin de su personaje es altamente complejo: había compasión por otra persona cuando antes, paradójicamente, existía una ambigüedad identitaria, tanto externa - las correrías de madrugada vestido de mujer para atraer hombres - como interna - los sentimientos de afecto, aun cuando no había parentesco alguno con los huéspedes-. Con ello, Bellatin parece indicar que solo en una convulsión, donde los contrarios se imbrican (orden/caos; femenino/masculino; normal/anormal; humano/bestia), puede surgir una tendencia natural hacia la humanidad. Por contraste, cuando el protagonista experimenta esta transformación interna, que se expresa en quietud y al fin en tranquilidad en su vida, toda empatía se desvanece. Es relevante repasar una escena, extremadamente representativa de este instante, para notar con exactitud dicha transformación:

[E]ra un muchacho de unos veinte años, que ya había comenzado con la disminución de peso y los ganglios. Cierta noche lo encontré tratando de huir. Fue tal la paliza que le propiné, que muy pronto se le quitaron las ganas de escapar. Se mantuvo acostado en la cama, esperando pacíficamente que su cuerpo desapareciera después de pasar por las torturas de rigor. (36)

La pregunta parece obligada tras observar este episodio: ¿se trata, entonces, solamente de un moridero?, ¿no estará, dicho salón, pasando por una segunda mutación, más vinculada con los procesos interiores del protagonista? Es por ello que más atrás se argumentaba que el salón se fusiona de tal modo con la nueva personalidad del narrador que cualquier alteración en este nuevo sistema es asumida por él como una fisura identitaria. Instalado ya en un orden de tipo fundamentalista, el protagonista comienza a negarse conscientemente uno de los grandes campos emocionales que humanizan (la empatía), haciendo que sobrevenga la monstruosidad: "[H]abía sido testigo ya de tantas muertes, que comprendí muy pronto que no podía echar sobre mis espaldas toda la responsabilidad de las personas enfermas. Con el tiempo logré hacer oídos sordos, tanto a las súplicas como a la animadversión de algunas personas" (37).

Repasemos: de salón de belleza en moridero; y de moridero en institución deshumanizada, donde lo que se preserva, para su correcto y perpetuo funcionamiento, no es al enfermo sino el trabajo en torno a la enfermedad. "Después de unas cuantas jornadas de convivencia", explica el narrador en este punto, 
"logro establecer la atmósfera apropiada. Se trata de un estado que no sabría cómo describir con propiedad. Logran el aletargamiento total donde no cabe, ni siquiera, la posibilidad de preguntarse por sí mismo. Ése es el estado ideal para trabajar. Así se logra no involucrarse con ninguno en especial haciéndose, de ese modo, más expeditivas mis labores. De esa forma se cumple con el trabajo sin ninguna clase de impedimento". (39)

El trabajo en el moridero —u "oficio", como acaba nombrándole con implacable rigor- va convirtiendo a los humanos en cuerpos inertes, indignos, que no pueden huir (pues pondría en riesgo la perpetuidad del recinto); que no son tocados "con fines ajenos a los higiénicos" (40); que guardan cierto sentimiento positivo hacia la institución, pero solo por el privilegio de haber sido admitidos al encontrarse cosificados por la enfermedad; y que, al morir, "sus cuerpos son envueltos en sudarios que yo mismo confecciono con parte de las telas de sábana que nos donaron. No hay velorio. Se quedan en sus camas, hasta que unos hombres que tengo contratados los trasladan en carretillas [...] [y] van a dar a la fosa común" (40).

Bellatin sabe trabajar bien, en Salón de belleza, los ciclos de perturbación y de tranquilidad en la vida del protagonista, cuyas circunstancias y espacios exteriores, como se ha visto, no son más que proyecciones personales. En los momentos de mayor movimiento y violencia (la búsqueda de clientes, travestido; los primeros compases del salón de belleza; las primeras épocas del moridero), hay humanización. En los momentos de mayor estabilidad y orden (el moridero como institución), hay monstruosidad. Sobrevendrá, en la parte final, un momento inevitable, anunciado anteriormente: la enfermedad no solo abarcará todo aquello que le rodea, sino su continente corporal.

Lo que en un comienzo se asumía como una amenaza, comienza a concretizarse. El moridero, pues, le ha servido todo este tiempo para comprender la evolución de la enfermedad, sus síntomas y su golpe final. Haberse rodeado de dicho fenómeno no solo le ha dado la conciencia de que probablemente muera, sino la narrativa completa de cómo y por qué morirá. No es gratuito, entonces, que todo aquello se manifieste a través de un brote neurótico:

Los primeros síntomas del mal los sentí en mi cuerpo cierta mañana, en que desperté más tarde que de costumbre. Se trató de un amanecer algo extraño. Con las primeras luces del alba, me sobresaltó una pesadilla. Soñé que regresaba al colegio donde había estudiado la primaria, y nadie me reconocía. Si bien es cierto que en apariencia tenía el mismo aspecto de cuando era niño, había cierto elemento en mí que delataba el paso de los años. Era algo así como un hombre viejo en un cuerpo de niño. Pasé revista a mis compañeros de salón y a algunas profesoras. Eran los mismos con los que había estudiado, pero me trataban como a un desconocido al que, además, le tuvieran miedo. Finalmente, mi madre fue por mí a la salida y con ella ocurrió lo mismo. Había ido por mí y, sin embargo, no era capaz de reconocerme. Desperté con una tristeza profunda. (43-44)

Finalmente, ¿cuál es el rasgo más aguzado de la monstruosidad? Sin duda, la alteridad radical; aunque el monstruo, en su trasfondo siniestro, sea capaz de almacenar aquello que el individuo tomado por normal ha querido ocultar de su propia naturaleza. El verdadero monstruo humano es segregado de su entorno afectivo más inmediato (en este sueño, el niño-viejo es desconocido y hasta temido por sus compañeros y maestros de la escuela, y luego por su propia madre), marginado a ser consciente de una existencia que, con mayor razón por una enfermedad terminal, se le acaba. La novela finaliza con una inquietante frase: "Ahora lo único que puedo 
pedir es que respeten la soledad que se aproxima" (53), dando entender el último giro: al participar, ahora como huésped, del propio recinto mortuorio que ha creado, el narrador se desvanece en la propia narración y la novela se cierra hacia adentro. Se comprende, entonces, después de los varios ciclos de movimiento/tranquilidad, el epígrafe elocuente de Yasunari Kawabata que abre Salón de belleza: "Cualquier clase de inhumanidad se convierte, con el tiempo, en humana" (26).

Una palabra más, antes de terminar, sobre un elemento que cruza transversalmente toda la novela y que parece derivarse en una notable narración paralela: las peceras. Este relato no concatena sus mutaciones como "Axolotl", de Julio Cortázar, ${ }^{9}$ aunque parece coquetear con dicho cuento. Ese devenir monstruoso, al decir de Gilles Deleuze y otros, se presentaría de manera positiva al asumir que el propio cuerpo es un obstáculo y que, al mixturarse, avanza hacia otro estado más libre. No obstante, creo que la propuesta de Mario Bellatin es más compleja todavía, cuando, por un lado, los peces se convierten en elementos que asimismo reflejan la fractura interna del protagonista y sus propósitos; y, por otro, cuando parece que, debajo de una apariencia afable, su propia naturaleza bestial se manifiesta.

En un comienzo, las peceras están ahí, con gupis y monjitas: peces coloridos que, al formar parte de la escenografía del salón, le permiten a las clientas tener la sensación de un mundo donde la belleza se renueva y permanece, en comparación con la degradación y la fealdad que puede vivirse en la calle. Pero luego, el narrador nota que la vitalidad de los peces, al ser fuertemente contrastante, puede ser inapropiada para el moridero. Los peces amables, entonces, bien son reemplazados por otros de comportamiento más intrincado; bien comienzan a sufrir padecimientos, del mismo modo que los seres humanos allí dispuestos. La mixtura entre lo humano y lo animalesco, entonces, es más enrevesada en Bellatin, al menos por dos razones. Primero: en el relato de Cortázar, el personaje que se paseaba por el Jardín des Plantes se volvía efectivamente un ajolote, mas conservaba su punto de vista humano. En cambio, el protagonista de Salón de belleza, por más voluntad que tenga, verá que esa barrera entre lo humano y lo bestial es infranqueable, y su único punto de contacto entre él y las bestias es una naturaleza depredadora. "Los ejemplares más extraños que alguna vez he criado han sido los llamados Ajolotes" (45), afirma categóricamente, al narrar cómo quiso, en un momento, hacerlos convivir con aquella especie que limpia los acuarios: los llamados "Peces Basurero". "[A]penas dejé el acuario los dos Ajolotes se lanzaron a devorar a los Peces Basurero. Regresé a los pocos minutos, y me encontré con la carnicería. Los Ajolotes estaban nuevamente, al fondo del acuario. En apariencia estaban tranquilos, pero de sus bocas sobresalían partes de los peces que se habían tragado" (46). Lo que en un comienzo le causa temor, es asumido, en el comentado tránsito de deshumanización del moridero a la institución, como una condición natural: para conservar la

\footnotetext{
9 "Oscuramente me pareció comprender su voluntad secreta, abolir el espacio y el tiempo con una inmovilidad indiferente. Después supe mejor, la contracción de las branquias, el tanteo de las finas patas en las piedras, la repentina natación (algunos de ellos nadan con la simple ondulación del cuerpo) me probó que eran capaces de evadirse de ese sopor mineral en que pasaban horas enteras. Sus ojos, sobre todo, me obsesionaban [...]. Ahora soy definitivamente un axolotl, $y$ si pienso como un hombre es sólo porque todo axolotl piensa como un hombre dentro de su imagen de piedra rosa" (Cortázar, 2007: 519, 522. El énfasis es mío).
}

Felipe Adrián Ríos Baeza: "Una belleza incómoda: anormalidad y monstruosidad en Salón de belleza, de Mario Bellatin" 
apariencia de tranquilidad, se ha debido ejercer la violencia hacia otro (los ajolotes se comen a los peces basurero; él propina palizas a quienes desean huir del salón).

Y segundo: son los propios peces los que le permiten transmutar la anormalidad de la enfermedad en un signo, privado y simbólico, de consideración especial (y así exigir, en la frase final de la novela, el "respeto por la soledad que se aproxima"). En un momento, después de la apacibilidad de los gupis y las monjitas, y del comportamiento depredador de los ajolotes, el narrador nota que algunos peces son atacados por hongos. Los ejemplares afectados se han vuelto deformes, repugnantes, pero se han ganado, a cambio, el respeto de sus depredadores. Es justo esa anormalidad, por tanto, la que los dota de un estatus superior: "En más de una oportunidad realicé cierta prueba donde queda claro que los peces atacados por los hongos se volvían sagrados e intocables. Por más que les pusiera ajolotes o pirañas en su pecera, eran respetados en forma absoluta. Cualquier pez con hongos sólo muere de ese mal" (48). Tener conciencia de que se morirá de un mal interno, y no por la agresión de otro de la misma especie, eleva tanto a los peces contagiados como al narrador a un rango de mayor dignidad.

Así, puede evidenciarse que Salón de belleza está profundamente marcada por instancias de mutación, anormalidad, enfermedad y monstruosidad, asunto que, por supuesto, va más allá de las aparentes deformaciones. En este sentido, es posible entender que lo monstruoso, en tanto condición de inhumanidad y amenaza a la normalidad social, puede darse tanto en situaciones tanto externas (cuerpos degradados por el virus, focos de contagio) como internas (procesos de desensibilización, depredación). Lo cierto es que, en los momentos de mayor duda y reflexión del personaje principal, hay un impulso de acercarse a lo animalesco:

A veces, cuando nadie me ve, introduzco la cabeza en la pecera e incluso llego a tocar el agua con la punta de la nariz. Aspiro profundamente, y siento que de aquella agua emana aún algo de vida. A pesar del olor del líquido estancado, puedo sentir todavía cierta frescura, lo que más me sorprende es lo fiel que se ha mostrado esta última camada de peces. Pese al poco tiempo dedicado a su crianza, se aferran de una manera extraña a la vida. (34-35)

Manera que, como se ha podido ver, los huéspedes no tienen, y allí donde los humanos se abandonan a una muerte rápida, los animales luchan por su sobrevivencia. El narrador lo sabe en los momentos finales, y por eso reclama un gesto final, nuevamente estético, nuevamente bello: "Uno de los hechos que me entusiasman con el final del Moridero, es que nuevamente los acuarios tendrán su pasado esplendor [...]. Para ese entonces, en el salón de belleza estarían las nuevas peceras junto a los flamantes implementos de belleza. No habría clientas, el único cliente del salón sería yo. Yo solo, muriéndome en medio del decorado" (51).

Una muerte grotesca, debido a los embates de una enfermedad, en un decorado lleno de vitalidad y de belleza.

Es una buena imagen de lo que provoca leer a Mario Bellatin.

Felipe Adrián Ríos Baeza: “Una belleza incómoda: anormalidad y monstruosidad en Salón de belleza, de Mario Bellatin" 


\section{Bibliografía}

AGUILAR SOSA, Yanet: "Mario Bellatin gana la primera batalla contra Planeta-Tusquets", El Universal, http://www.eluniversal.com.mx/articulo/cultura/letras/2015/10/30/mario-bellatingana-la-primera-batalla-contra-planeta-tusquets, 10/05/2016.

BELLATIN, Mario (2005): "Salón de belleza". En Obra reunida 1. México, Alfaguara, 25-53.

CORTÁZAR, Julio (2007): “Axolotl”. En Cuentos completos 1. Buenos Aires, Punto de Lectura, 517-522.

FOUCAULT, Michel (2000): Defender la sociedad. Curso en el Collège de France (1974-1975). México, Fondo de Cultura Económica.

FOUCAULT, Michel (2006): Los anormales. Curso en el Collège de France (1975-1976). México, Fondo de Cultura Económica.

FREUD, Sigmund (1968): “Lo siniestro". En Obras completas VII. Madrid, Biblioteca Nueva, 2483-2500.

MORALES, Francisco: "Denuncia Mario Bellatin libro desautorizado", Reforma, http://www.reforma.com/aplicacioneslibre/preacceso/articulo/default.aspx?id=644506\&urlredirec $\mathrm{t}=\mathrm{http}$ ://www.reforma.com/aplicaciones/articulo/default.aspx?id=644506, 10/05/2016.

RODRÍGUEZ MARTÍNEZ, Elvis Nel, y Nelly GARCÍA GAVIDIA: "Enfermedad y significación: Estigma y monstruosidad del VIH/SIDA”, Opción, XXII/ 50 (2006), 9-28, http://www.scielo.org.ve/scielo.php?script=sci_arttext\&pid=S1012-

$15872006000200002 \& \operatorname{lng}=$ es\&tlng=es, 10/05/2016.

(C) Felipe Adrián Ríos Baeza

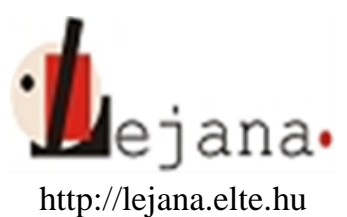

Universidad Eötvös Loránd, Departamento de Español, 1088 Budapest, Múzeum krt. 4/C

Recibido: 24 de mayo de 2016

Aceptado: 04 de julio de 2016

Felipe Adrián Ríos Baeza: "Una belleza incómoda: anormalidad y monstruosidad en Salón de belleza, de Mario Bellatin" 